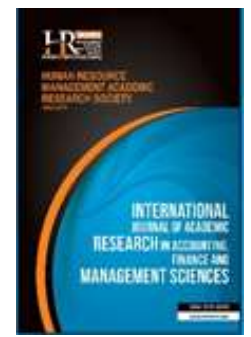

International Journal of Academic Research in Accounting, Finance and Management Sciences

Vol. 9, No.4, October 2019, pp. 304-319

E-ISSN: 2225-8329, P-ISSN: 2308-0337

(C) 2019 HRMARS

www.hrmars.com

To cite this article: Abiloro, T.O., Olawole, A., Adeniran, T.E. (2019). Corruption, Income Inequality, and Economic Development in Nigeria, International Journal of Academic Research in Accounting, Finance and Management Sciences 9 (4): 304-319

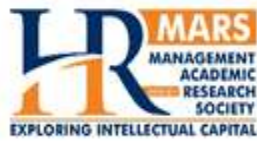

\title{
Corruption, Income Inequality, and Economic Development in Nigeria
}

\author{
T. O. Abiloro', A. Olawole ${ }^{2}$, T. E. Adeniran ${ }^{3}$ \\ ${ }^{1}$ Bursary Department, Rufus Giwa Polytechnic, Owo Ondo state, Nigeria, ${ }^{1}$ E-mail: tobanson316x@yahoo.com \\ ${ }^{2,3}$ Accountancy Department, Rufus Giwa Polytechnic, Owo Ondo State, Nigeria
}

\begin{abstract}
The relationship between corruption, income inequality, and economic development has been a major concern and of course an area of continuous debate because of their devastating effect on economic development. Therefore, the broad objective of this study is to empirically ascertain the impact of corruption and income inequality on economic development in Nigeria. This study employed a factorial research design. The data for analysis was mainly secondary and obtained from World Bank Data, CBN Statistical Bulletin, Transparency International and United Nation Publications. The population of this study consists of data from 1999 to 2017 which is nineteen (19) years. Two control variables were introduced (Education Level and Population Growth) in order to minimize omitted variable bias. The study adopted the ordinary least square regression model. The findings of this study revealed that both corruption and income inequality have significant effect on economic development and are both negatively correlated. This shows that increase in corruption and income inequality will have negative impact on economic development. The study therefore recommends that the government should intensify more efforts in battling corruption within the country through the use of forensic investigative skills in detecting corrupt activities which will now serve as a deterrent for any individual who may want to involve in the act. Also, technological tools should be used to develop institutional trust and block all international loopholes to discourage money laundering.
\end{abstract}

Key words Economic Development, Corruption, Income Inequality, Population Growth, Education Level

Received: 12 Jan $2020 \quad$ (C) The Authors 2019

Revised: 20 Jan 2020 Published by Human Resource Management Academic Research Society (www.hrmars.com)

Accepted: 22 Jan 2020 This article is published under the Creative Commons Attribution (CC BY 4.0) license. Anyone may reproduce, distribute, translate and create derivative works of this article (for both commercial and non-commercial purposes), subject to full attribution to the original publication and authors. The full terms of this license may be seen at: http://creativecommons.org/licences/by/4.0/legalcode

\section{Introduction}

The relationship between corruption, income inequality, and economic development has been a major concern and of course an area of continuous debate because of their devastating effect on economic development of any society and inconsistent conclusion drawn by different researchers in establishing the relationship that exist between these variables. Though these two factors are not new but they have been ancient universal issues and considered as factors that can affect the economy of any country. Ambar (2015) described corruption as a deadly virus which has the power to attack the vital structures required for a society's progress and also a major obstacle to economic development of any country. Social trust has become a thing of the past due to corruption and this has resulted to inequalities in the system which had a negative impact on the general public education, health care, and labourers' wage rate (Rothstein and Uslander, 2005).

Transparency International [TI] (2009) described corruption as the wrong use of entrusted political power. Ambar (2015) also posited that corruption is the transfer of interest from the public for personal 
gain or the abuse of public office for individual's private benefit. Ugur and Dasgupta (2011) described corruption as the greatest hindrances for the long run social development and also development of economy mostly in countries that are developing because it damages the institutional structure of government badly.

Generally, corruption is viewed paradoxically on whether it is harmful or beneficial to the economic development of any society. Mauro (1997) concluded that corruption is more damaging to the development of economy as it causes slower growth. Knack and Keefer (1997) also pointed that government parastatals, ministries and agencies involve in a very high degree of corruption which affects economic development negatively (in terms of investment and growth).

Ritva and Jakob (2005) on the contrary posited that corruption can also grease the wheels of prosperity, majorly in the place where bureaucracies and organizations are inefficient i.e. entrepreneur and big firms struggle to transport or export or comply with regulations, that corruption could improve efficiency and development or piece rate, giving better and faster service to firms with highest cost of waiting. Chris (2014) on his argument on whether corruption can seemingly be helpful opined that it is not necessary we call it corruption, because it can help in achieving some legs. He noted that since we are in an imperfect world, which if corruption is a bit controlled it can function as a lubricant in overcoming some of our worst problems. Therefore in his view, if the looted funds recovered in the past are appropriately invested in the economy, it can in turn positively affect the economy.

Corruption does not only affect economic development but also the distribution of income which has led to income inequality. This is because it is only those closely connected to the ruling class in the government that belongs mostly to the high income group (Gupta et al., 2002). Moreover, as evident in a developing country like Nigeria, political cabals and their relations are those that benefit more from the wealth of the Nation. They embezzle the wealth that is due to the citizens of the country and save it in both local and international banks while some hide it in a secluded place in their apartment, instead of investing such funds into the economy which can in turn develop the economy. This has however increased income inequality among the citizens and affects economic development negatively because the wealth of the nation is one-sided.

Although the study of the effect of corruption and income inequality on economic development has become prominent in research field majorly in the developed countries. Mauro (1997) stated that corruption has both negative and significant effect on economic development because it leads to decrease in human capital investment. Tanzi and Davoodi (1997) discovered that corruption increases government general expenditure but reduces expenditure on maintenance which reduces economic development because it will be difficult to put new capital into use due to lack of complementary inputs. Wei (2000) concluded that corruption decreases private investment and human capital investment which is the channel through which it affects economic development. Benabou (1994); Banerjee and Duflo (2000); and Wahiba (2014) concluded that income inequality have a negative impact on economic development because people with less social capital, educations, access to health have difficulties in accessing jobs, credit availability for investments and so on, which is not true in an egalitarian society where everyone have access to sound education, health and social benefit which can in turn improve economic development. All these empirical researches mentioned above were conducted on developed countries. In developing countries however, there are but few empirical work on corruption, income inequality and economic development in this recent era where corruption is so rampant. For instance, the few known empirical studies conducted on corruption, income inequality and economic development in Africa are that of Kwabena (2002) on African countries as a whole and Egunjobi (2013) in Nigeria, they both concluded that corruption increases income inequality and decreases economic development in African countries.

Moreover, findings on the relationship between corruption, income inequality and economic development have been inconsistent over the decades, Ambar (2015); Josh (2014); and Mauro (1997) have seen a negative effect on economic development while Chambers (2005); Chris (2014); and Forbes (2000) found a positive relationship between corruption, income inequality and economic development. They noted that if controlled, corruption can serve as a lubricant in overcoming some of our worst problems, that if recovered looted funds can be appropriately re-invested into a country's economy, it will improve the economy of such country. 
Kwabena (2002) investigated corruption, income inequality and economic development in Africa some years ago, where he used Panel Estimator and Generalized Least Square (GLS) model as regressor. Though he used corruption perception index and gini coefficient to measure corruption and income inequality but the result gotten cannot be relied upon in concluding the impact of corruption and income inequality on economic development in Nigeria due to the facts that all these African countries put together are not having things in common, in terms of their population, economy, education level, corruption ranking and so on. Justice would be done, if a particular country is focused on. Focusing on Nigeria alone will be justifiable majorly in this era where the major song is "anti-corruption crusade". The known study conducted on Nigeria was done by Egunjobi (2013) and covered period from 1980 to 2009. He uses total labour force and incidence of bribery recorded to measure corruption. The question here is that, how can incidence of bribery be reliably determined in Nigeria? This is not documented anywhere because there are high level of unreported cases of bribery in Nigeria, therefore using this as a basis for measuring corruption is not justifiable. This study is also different from prior studies because it uses shorter and more recent period data. Therefore, the gap this study tends to fill is to address the problem of inconsistent results, inconclusive findings, unreliable measuring method and outdated results gotten in the prior studies.

\section{Literature review}

This chapter reviews literature on corruption, income inequality and economic development. Different concepts were reviewed, sociological and modernization theory of corruption, the fraud and the new fraud diamond were reviewed, and review of empirical studies was also examined. All these will be necessary in establishing gap on which this study is based.

\subsection{Economic Development}

Economic development is a medium through which a nation improves both the economic, political and social well-being of its citizen. It is also described as the major objective of the nations in the world, the objective is quite simple: to create the wealth of a nation. Many developing countries in the years back have experienced an improved growth rate of per-capital income but not evident in the living conditions of the major part of the country's population. Seers (1969) observes that the aim of development is for the per-capital income of the citizens to increase but this have not been the case as inequality, poverty and unemployment are still growing worse. Seers now highlighted the changes needed in setting economic development objectives which should not be limited to just growth but to also concentrate more on the reduction of inequality, poverty and unemployment.

Stiglitz (1998) notes that it is the kind of life people are living that determines whether people are from developed, developing or underdeveloped country. Stiglitz further observed that the kind of death, diseases, sickness, mal-nourishment that happens day-in-day-out mostly in developing and underdeveloped nations has changed the developmental goal dramatically. Stiglitz further concluded that a shift in developmental goal is needed by governments of developing countries so as to widen the objectives to include improvement in income distribution, environment, health and education, and broadly to ensure improvement in the general quality of life of the citizen. Sen (1999) observed that the very main goal of development is to improve human capabilities, which means the freedom that a person has in terms of choice of performing functions, giving personal characteristics into functioning and commands over commodities.

\subsection{Corruption}

Association of Certified Fraud Examiner [ACFE] (2010) develops model for categorizing known frauds, which is known as fraud tree. They listed about 49 different fraud schemes grouped by categories and sub categories. The three major categories stated by them were: Fraudulent Financial Statements; Asset Misappropriation; and Corruption. The study will only consider on aspect of fraud major categories, which is corruption. Corruption involves a number of schemes, such as bribery, extortion distortion, illegal gratuities, kickbacks, related-party activity and so on, which is committed majorly by an employee of any 
public organisation in other to gain undue advantage or benefit at the expense of the organisation damage (ACFE, 2010).

Corruption is a form of behavior that deviate from general belief, ethics, traditions, morality, law, civic virtue and so on, it can either be both monetary (Financial Corruption) and non-monetary (Kelly, 2015). For the sake of this research, more focus will be on the monetary aspect while to some extent the non-monetary will be looked into. Corruption connotes different meaning to people depending on individual's ideology, discipline, cultural background, level of exposures and political leaning. Corruption has been earlier defined in this paper as the abuse of public office for personal gain. Public in this context connotes private businesses, international organisations, corporations, government ministries and agencies, government parastatals and public liability companies.

In the public sector, corruption or level of corruption usually connotes two common meaning. The first leg stands for those unethical practices whereby organisations or individuals bribe officials which have responsibilities of awarding contracts or at times to be freed from punishment of a particular offence committed (that is, getting or obtaining undue privileges as against the law or against some bureaucratic rules) and secondly are those unethical practices where officials saddled with the responsibilities of awarding contracts extorts organisations or individuals before awarding any contract (that is, economic extortion). Klitgaard (1998) viewed corruption broadly as the misuse of office for unofficial ends and also narrowly concluded that it is the achievement of several advances by the way of personal networking, payment of gratitude, money or gift for normal services (popularly known as PR). Johnson (1994) defined it as every dangerous, illegal and immoral act in the public and private sector.

Klitgaard (1998) gave certain formula on how corruption takes place. He said it is the monopoly of power, and a combination of it with lack of accountability and discretion. He further gave the formula as: $\mathrm{C}=\mathrm{M}+\mathrm{D}-\mathrm{A}$, where $\mathrm{C}$ represents corruption, $\mathrm{M}$ means monopoly, $\mathrm{D}$ connotes discretion and $\mathrm{A}$ represents accountability. This formula was again modified by United Nation Development Programme [UNDP] (2004) with the addition of two extra dimensions, which are Integrity and Transparency. UNDP now changed the formula to $C=(M+D)-(A+I+T)$. This means that the absence of AIT (Accountability, Integrity and Transparency) which is primarily a major reason for weak governance. In addition monopoly and discretion will also result in corruption. This formula is what gives strength to the theory that concluded that corruption means an absolute failure in governance.

Jenny and Erlinda (2006) see corruption as the result of politics of privilege and rent seeking. He said corruption is nurtured by the so-called politicians who through lies and deceit played on the intelligence of their supporters and followers so as to engage in corruption and restrict the benefit to some certain people (favoritism), whereby those derivable benefits are majorly concentrated on only small section of the population while leaving large number of the population in hunger and poverty.

Owolabi et al., (2013) note that many countries had enacted laws to eradicate the existence of corruption by setting up tribunals, probe panels and anti-corruption institution. They pointed that in Nigeria, there are institutions such as Economic and Financial Crime Commission (EFCC) and Independent Corrupt Practices and Other Related Offences Commission (ICPC), yet this does not reduce the existence of corrupt practices which shows that most of this commission lacks forensic investigative skills to ensure successful prosecution of person charged for corrupt practices, which could have served as a lesson to all others who have such intent.

Dada (2014) posits that there is a need for an effective investigation of skills and techniques that can actually help the anti-corruption institution in successfully curbing the menace of corruption which might have significant and positive relationship on income inequality and economic development. He suggests that forensic accounting techniques have an antidote to curbing this menace because it gives an accounting analysis that is suitable in the court and form basis for debate, discussion and financial dispute resolutions.

\subsection{Drivers of Corruption as it relates to Economic Development}

There are so many variables that drive corruption and have affected economic development greatly; some of these variables are public procurement corruption, bribery, nepotism. These variables are discussed below: 
a. Public procurement corruption: public procurements are various kinds of acquisition that is done on public goods and services. Such procurement is expected to be carried out in accordance with the laid down principles of the International Competitive Bidding (ICB). ICB covers each procedure by designing tender for the evaluation and contract award. Public procurement corruption occurs when we have a clear misuse of public office, and that the person involve derive a direct identifiable benefit from the act and that such benefit must be a direct return from the act. Such a corruption is negatively affecting economic development, also distort market mechanisms and create inefficiencies by reducing competitiveness, foreign direct investment and trade (Soreide, 2002).

b. Bribery: Hamra (2000) defines bribery as the offering, promising or giving an item of value so as to induce or influence a public official in the executions their official duties. Bribe can be in form of money, material items and other pecuniary or non-pecuniary benefits. Mauro (1995) finds a negative relationship between bribery and economic development which later concluded that prevalence of bribery is a barrier to economic development; therefore a reduction in bribery can have a cleansing effect on the economic environment in the conduct of economic activities. Hamra (2000) opined that bribery is a deterrent to trade, investment and commercial activities within the country and that bribery is taking much lower in countries with higher incomes because most employees will be well satisfied with what they earn.

c. Nepotism: is described as that variety of practices that relates to favoritism, it simply means to hire and advance unqualified or under-qualified family members based on familiar relationship. TahaBarakat (2016) points out that nepotism is the acceptance of public employee to please or pressurize others on the violation of law to implement the request of their needs without any right and therefore it is considered a breach of the functional lead to looting right or the realization void and ultimately a waste of public money which is harmful to economic development.

Gjinovci (2016) noted that nepotism is the reason behind political and family influences on the various forms of employment to different public positions in a country. He pressed further that this employment includes those ones to: important sectors in the economy; public administrations; management staff of the ministry; security bodies; public corporations; and public media without necessarily reviewing the qualifications, technical know-how and the skills of such personnel. This has in turn had a negative impact on the economic development because these personnel are inefficient and ineffective which has resulted into low output.

\subsection{Income Inequality}

Inequality means the state of not being equal, mostly in status, rights and opportunities (Jorge, 2011). It is however prone to confusion majorly in public debate because it connotes different meaning to different people, though there are common distinction. Many scholars see economic inequality to be the same thing as income inequality or monetary inequality or more broadly seeing it as inequality in living conditions, but for this study, income inequality will be used and focused on. Income inequality is the unequal distribution of individuals' income among the various participants of the economy (Jorge, 2011). Based on history, income inequality has affected or was affected by economic development of average income earner of the nation. Some other studies show that development had an inconclusive effect on inequality, but income inequality is seen to be detrimental to economic development.

Christian (2013) defines income inequality as the means of distributing money income which is quite different from economic inequality. Atkinson (1970) noted that income inequality idea is based on how income is improperly distributed among the individuals or groups in a society, state or country. In measuring income inequality data can be gotten from different settings, different classes within a society, different professions, or different genre, and that income inequality has a propensity to look at the economic conditions for both groups and individuals while economic inequality is the different between economic condition of different individuals or different groups, the reason is that income appears to have substantial significance for a person's standard of living. What originates or determines income inequalities can be some factors such as the structure of political governance, corruption, political governance, institutional stability, inborn ability, race, education, labour, culture, gender, population and so on (Christian, 2013). 


\subsection{Drivers of Income Inequality as it relates to Economic Development}

There are many variables that drive income inequality which have greater effect on economic development; some of these variables are poverty, social welfare, education and health, and so on. These variables are discussed below:

a. Poverty: this is the deprivation from certain basic things of life, such as clothing, food, good shelter, good drinking water, health care and basic minimum education opportunities. Dollar, David and Kraay (2001) notes that economic development may reduce poverty by raising the incomes of every citizen in the country. Ugwu (2012) also in agreement with the above posited that higher growth could be associated with increased standard of living and asserted that economic development can enhance poverty reduction. The most effective tool for reducing poverty is economic development and can thereby improve the quality of people's life because growth can generate prosperity and employment opportunities that will improve people's living standard. Though, the extent and level to which growth reduces poverty depends on the level or degree of poor people participation in the growth process and what they get in its proceeds (Besley and Cord, 2007).

b. Social Welfare: this is concerned with the well-being of the entire society, though it is not the same as living standard but it is more concerned with the quality of life which includes factors such as quality of the physical environment in terms of air, soil, water and availability of certain essential social services. Bambra (2004) notes that well-being is one of the most germane aspects of human lives and that as economic development creates wealth; social welfare is that one important factor that ensures effective distribution of that wealth. It is mostly measured as happiness, satisfaction with life, having a meaningful life, fulfilling one's potential and feeling that we live a worthwhile life (Eckersley, 2004). Therefore, the availability of social welfare is an indication of effective economic development.

c. Health and Education: increased productivity is what indicates economic development which can be achieved through appropriate investment in labour and capital. Meanwhile, investment in capital can be fully utilized if there is healthy and educated workforce in the economy. Health and education are very germane instruments in the productivity improvement and economic development; good health will not only give longer life span but also helps in raising returns on investment in education because a healthy educated person will work hard to ensure productivity of the economy. Education also speeds up technological advancement and increases the probability of more healthy productive children which will enhance economic development (Tato, 1998).

Arias et al., (2013) notes that poor people tend to under-invest because they are always myopic in their decision making process which causes an inability to effectively internalize the returns on education and health. For this reasons, many children from developing African countries have a sub-standard education level and health attainment. Children born in lower class families are prone to experiencing malnutrition, illness, environment less conducive for learning and lower quality of schooling. They therefore have lesser motivation to learn which result to increase income inequality and affects economic development negatively. Jorge (2011) notes that the most important determinants of any individual's future income is education. That the prevailing policies on education and several variations to accessing quality education in any country can significantly affect income inequality positively. Jorge also pointed out that in a society where there are poor access to education by the general masses, that it is only the few citizen who were able to sponsor themselves to obtain education and required skills that will be allocated a good working position that gives high income and thus widening the gap between the incomes of the educated and uneducated population.

\subsection{Relationship between Corruption, Income Inequality and Economic Development}

Corruption has continually been attracting a great number of attentions because many studies have present persuasive evidence as regards its negative effect on some economic variables such as income growth. The likes of Knack and Keefer (1995); Mauro (1995) and Hall and Jones (1999) find out that corruption reduces income growth significantly. Shleifer and Vishny (1993) noted that, a weak central government ministries, departments and agencies to impose bribe on the sales of complementary government goods such as licenses and permits. He further noted that the increased in the number of these agencies day in day out has given rise to corruption resulting to reduction of investment and 
development. In the studies by Huntington (1968), he argues that the modernization of politics from an autocratic government to a democratic one has over the years weakens the central government power and thereby increasing corruption through the changes it produces on the output side of political system. Gupta et al. (2002) was of the opinion that corruption does not only have effect on economic development but also have a greater effect on the income distribution because the benefits from corruption are likely to accrue to the better connected individuals. Inequality affects development in three ways: redistribution, weaker institution handling external shock and credit market imperfection (Sachs, 1989).

Li et al. (2000) examine corruption effect on income and the Gini coefficient of income distribution using data from Asian, Organisation for Economic Co-operation and Development (OECD), and Latin American countries. They were able to conclude that corruption increases the Gini coefficient in a quadratic way; the Gini coefficient is higher for countries with intermediate level of corruption while it is low for countries with high or low levels of corruption. They also opined that corruption affects the Gini coefficient through government consumption. They however, do not allow economic growth to influence the Gini coefficient. Gupta et al. (1998) posited that corruption enhances income inequality using developing countries sample and also concluded that increased corruption is associated with decreases in the share of government expenditures devoted to education and health care. Hendriks, Keen and Muthoo (1998) found that the distributional effects of corruption and tax evasion are regressive, hence increases income inequality. Studies in Gupta et al. (2002); Li et al. (2002); and Kwabena (2002) shows that both corruption and income inequality influence economic development, they found out that corruption increases income inequality and concluded that income inequality is another channel through which corruption hampers economic development. All these studies concluded that these variables have negatively affected economic development.

\subsection{Theoretical review}

Generally, this work is centered on four basic theories which are sociological theory of corruption, modernization theory of corruption and the fraud and the new fraud diamond theory of corruption and is discussed below:

\subsubsection{Sociological Theory of Corruption}

It was propounded by two sociologists which were Karl Marx and Wright Mills in the 18th and 19th centuries, which covers the areas of development social life, social relationships of individuals, groups institution (Kendall, 2000). Karl Marx theory explained that human cultural values are very germane in a society and also noted that power and money are what shape the social structure of any society by developing struggles among different levels in the attainment of the best. He believes that the urge to attain wealth and power had negative effect on the society and also that the materialism and power make the difference in the society. The materialistic view is that people earn food, shelter, clothing and work for their living, this struggle is what brought about owners and labourers relationship, whereby the owners tend to gain abnormal profit by paying the labourer lesser than their worth which led to exploitation in the society.

This exploitation is what further leads to political domination which create classes in power for those people who are economically strong, stable and gain so much power to control the country economy while the general masses are being exploited which in turn affects economic development negatively (Campbell, 1981). Wright Mills theory on the other hand posited that people who have lots of power are in the position of making decision that has greater effect on economy (Stephens et al., 1998). These people with their power and resources shape the society and exploit people through corrupt means and thereby affecting economic development negatively. Kendall (2000) noted that a good society will only come into existence if the difference in powerful and powerless people are erased which will therefore bring about equality among the people. The latter action will reduce corruption and increase income inequality.

\subsubsection{Modernization Theory of Corruption}

One of the best ways to view corruption is when individual behavior go against the moral principles that guide their official obligations, therefore this theory view corruption as the breach of ethical rules that 
bind the conduct of individual's official duties (lyanda, 2012). Agubamah (2009) noted that there are several factors which would make successful way of fighting corruption difficult; these factors are the uniqueness of each society or country, the dynamic or changing nature of the socio political and economic interactions within the global community and the differences in the perception of the corrupt practices.

Modernization theory was propounded by Huntington in 1968, this theory was cited by Adefulu (2007) and he pointed that the process of economic and political development in modern societies has brought about inequality, corruption and political instability. Modernization theorist observed that the causes and incidence of corruption and corrupt practices in pre-colonial African communities in terms of the logic of patrimonialism, neo-patrimonialism, prebendalism and patro-clientelism. The main proportion common to all these theories majorly centers on the view that extractive corruption in African developing countries is one of the un-salutary consequences of grafting modern political structure and processes on indigenous socio political structure which functions on the basis of old values and responsibilities (lyanda, 2012). Adefulu (2007) sees corruption as an outcome of public officials' behaviours that deviate from the accepted values, norms and culture of the society, which also signifies ineffective political institutional structure presence that allows officials of the public to divert public funds for private use.

Huntington sees corruption as the origin of menace, and justified corruption as a political underdevelopment and inclinations of traditional societies which engage gift giving that is believed to be almost common in patrimonialism societies. He concluded his theory that corruption in African states generates inequality, political instability which has a negative effect on economic development.

\subsection{Empirical review}

Dincer and Gunalp (2005) carried out study on corruption, income inequality and growth with evidence from United States, using ordinary least square (OLS) method for data analysis and measured corruption through the use of the objective measure of corruption by considering the numbers of public officials convicted in a state for corruption related crimes and measured income inequality by employing 4year to 5-year panels of income inequality and growth in order to control for unobserved state characteristics. They found that an increase corruption will increase income inequality and decreases growth.

Viorica et al. (2011) analyze the relationship among corruption, economic growth and foreign direct investment (FDI) and also looked at the determinants of corruption using Romania time series data between year 1997 and 2009. The variables explored in this study were corruption, economic growth, FDI, education, governance economic freedom. They obtained their data from sources such as World Bank, Romanian Institute of Statistics and Eurostat. The findings showed there is both significant and positive relationship between corruption and FDI but found insignificant relationship between corruption and economic growth but they are correlated. The result also suggested that corruption have a significant relationship but negatively correlated to level of education, economic freedom and has a positive correlation with governance.

Kwabena (2002) examine corruption, economic growth and income inequality in Africa using the panel data that cater for different African countries and used ordinary least square (OLS) method as the regressor. The result showed that corruption decreases economic growth both directly and indirectly through the reduction of investment in physical capital. The findings also showed that an increased corruption will have a positive effect on income inequality. He noted that the combined effect of a decreased economic growth and an increased income inequality means that corruption really affects the poor negatively than the rich in African countries.

Kelly (2015) investigates into fraud and corrupt practices in public sector, focusing on the Cameroonian experience. The paper used agency theory to examine the level of fraud and corrupt practices in Cameroonian business and also carried out an evaluation on the effect of government anti-corruption policies on the menace of fraud and corrupt practices. The study adopted a survey research method to obtain data and the findings in this study showed that mostly all the segment of public sector involved in highly corrupt practices and have a negative effect on the economic development. He gave some examples that the Tax Administrators, Police and Customs are the most corrupt institution in the country. He concluded by saying the anti-corruption initiatives by the government are so ineffective which must have 
been as a result of the government insincerity and lack of political will to war against fraud and corruption in the system. Egunjobi (2013) investigates on the econometric analysis of the impact of corruption on economic growth in Nigeria. He used time series data from 1989-2009 and used GDP as a proxy for economic development, corruption index as a proxy for corruption and also developed some control variables such as government capital expenditure, foreign private investment, expenditure on education, total labour force and bribery. He use simple regression for the model estimation and found that corruption have direct effect on economic growth but indirect effect on education expenditure, capital expenditure and foreign private investment.

\section{Methodology of research}

This study employs a factorial research design. Factorial research design involves in a number of considerations such as different countries, the hypotheses being tested and also helps in understanding the effect of two or more independent variables on a single dependent variable. The source of collecting data for analysis was mainly secondary (from World Bank data, Transparency International, United Nation Publication and CBN Statistical Bulleting) which explore data on Nigeria for a particular period of time from 1999 to 2017. Ordinary Least Square Model was used for the data analysis. The whole population of the study will also be picked as sample because the population is just considering Nigeria for just nineteen (19) years. Two (2) control variables (Education Level and Population Growth) are introduced in order to minimize the omitted variable bias. Also, these control variables were added because they contribute to determining country's GDP per capita growth level (that is, they affect the speed at which a country economy converges towards its steady state and thereby resulting in economic development) (Eatzaz et al., 2012).

\subsection{Model Specification}

This study adapts and modifies a similar model applied by economic development equation that was popularized by Barro (1991) and estimated by other researchers (Caselli et al., 1996; Gyimah Brempong and Traynor 1999; Levine and Renelt 1992; Mankiw et al., 1992; Sachs and Warner 1997; Egunjobi, 2013). In its simplest form, the growth rate of income is assumed to depend on investment rate $(k)$, initial level of income $\left(y_{0}\right)$, growth rate of real export $(x)$, government consumption (govcon), and the stock of human capital which was proxied by the level educational attainment of the adult in the population (edu). In addition to these variables, corruption (cor) to measure the quality of institutions in an economy. The economic development equation in their studies in a linear form for the sake of simplicity is given as:

$$
E d v=\alpha_{0}+\alpha_{1} k+\alpha_{2} e d u+\alpha_{3} x+\alpha_{4} \operatorname{cor}+\alpha_{5} y_{0}+\alpha_{6} \text { govcon }+U
$$

However, there are other several important variables that also determine economic development in Nigeria. The levels of corruption, income inequality, literacy level, as well as population growth are some of these important determinants as far as Nigeria is concerned. In order to grasp the relevance of the objectives proposed in this study, these aforementioned variables are incorporated into the model and modifies as follows:

$E D V=f(C O R, I N Q, P O P G, E L)$

Equation (ii) above can be specified in a linear stochastic term as follows:

$E D V_{t}=\beta_{0}+\beta_{1} C O R_{t}+\beta_{2} I N Q_{t}+\beta_{3} P O P G_{t}+\beta_{4} E L_{t}+f_{t}$

Where:

EDV = Economic Development (proxy with GDP per capita growth)

COR= Corruption (proxy with Corruption Perception Index)

$I N Q=$ Income Inequality (proxy with Gini index)

$\mathrm{POP}=$ Population Growth (population growth rate)

$\mathrm{EL}=$ Education Level (education index)

$\beta_{0}=$ Constants $/$ Intercepts

$\beta_{1}=$ Coefficient of Corruption 
$\beta_{2}=$ Coefficient of Income Inequality

$\beta_{3}=$ Coefficient of Education Level

$\beta_{4}=$ Coefficient of Population Growth

$\mathrm{fl}=$ Error Term

The A-priori sign of the variables are: $\beta_{1}<0 ; \beta_{2}<0 ; \beta_{3} \geq 0 \beta_{4}>0$

Table 1. Operationalization of Variables

\begin{tabular}{|c|c|c|c|}
\hline $\mathbf{S} / \mathrm{N}$ & VARIABLES & OPERATIONAL DEFINITION & SOURCE \\
\hline 1 & $\begin{array}{c}\text { Economic } \\
\text { development }\end{array}$ & $\begin{array}{l}\text { Gross domestic product per capita growth of Nigeria for the period } \\
\text { stated. }\end{array}$ & Haq (1995) \\
\hline 2 & Corruption & $\begin{array}{l}\text { Corruption perception index (CPI) of Nigeria for the period as stated by } \\
\text { Transparency Organisation. The CPI scores relates to perception of the } \\
\text { degree of corruption by as experienced by business people, Auditors, } \\
\text { Forensic Accountants, Financial analysts and so on. It ranges between } \\
100 \text { (highly clean) and } 0 \text { (highly corrupt) }\end{array}$ & $\begin{array}{l}\text { Jain }(2001) ; \\
\text { Knoema (2018) }\end{array}$ \\
\hline 3 & $\begin{array}{l}\text { Income } \\
\text { Inequality }\end{array}$ & $\begin{array}{l}\text { Gini Coefficients of Nigeria for the period gotten from CBN Statistical } \\
\text { Bulletin. It measures } 0 \text { where everyone has equal income (perfectly } \\
\text { equality) and } 100 \text { when individual has all the income (perfectly } \\
\text { inequality) }\end{array}$ & $\begin{array}{l}\text { Wu et al. (2002) } \\
\text { Jorge (2011) } \\
\text { Ewubare and } \\
\text { Okpani (2018) }\end{array}$ \\
\hline 4 & Education Level & $\begin{array}{l}\text { Education index as published by United Nation: combining average } \\
\text { adult years of schooling with expected years of schooling for children. }\end{array}$ & $\begin{array}{l}\text { OECD (2004) } \\
\text { Hoffmeyer- } \\
\text { Zlotnik and Uwe } \\
\text { (2006) }\end{array}$ \\
\hline 5 & $\begin{array}{l}\text { Population } \\
\text { Growth }\end{array}$ & Population growth rate of Nigeria as published by United Nation. & $\begin{array}{l}\text { Sinding (2009) } \\
\text { O’Sullivian (2012) }\end{array}$ \\
\hline
\end{tabular}

\subsection{Data presentation and analysis of results}

Table 2. Descriptive Statistics

\begin{tabular}{cccccc}
\hline & EDV & COR & INQ & POPG & EL \\
Mean & 3.594737 & 21.42105 & 45.66789 & 2.601053 & 47.79474 \\
Median & 2.600000 & 24.00000 & 45.08000 & 2.580000 & 48.40000 \\
Maximum & 30.40000 & 28.00000 & 56.00000 & 2.700000 & 53.20000 \\
Minimum & -4.200000 & 10.00000 & 40.06000 & 2.520000 & 41.50000 \\
Std. Dev. & 7.069455 & 5.757274 & 4.704209 & 0.067897 & 4.149628 \\
Skewness & 2.976678 & -0.605696 & 0.950370 & 0.115604 & -0.332960 \\
Kurtosis & 12.26411 & 1.983183 & 3.036782 & 1.454764 & 1.875450 \\
& & & & & \\
Jarque-Bera & 96.00238 & 1.980266 & 2.861212 & 1.932627 & 1.352216 \\
Probability & 0.000000 & 0.371527 & 0.239164 & 0.380483 & 0.508593 \\
& & & & & \\
Sum & 68.30000 & 407.0000 & 867.6900 & 49.42000 & 908.1000 \\
Sum Sq. Dev. & 899.5895 & 596.6316 & 398.3325 & 0.082979 & 309.9495 \\
Observations & 19 & 19 & & & 19 \\
\hline
\end{tabular}

Descriptive statistics of the variables investigated in the analysis as displayed above. For instance, the average values for economic development stood at 3.594 and ranges from -4.200 to 30.40 while that of corruption stood at 21.42 and ranged from 10.00 to 28.00 . In addition, the mean value of income inequality stood at 45.66 but ranged from 40.06 to 56.00 over the years. It was discovered from the result that population growth rate has the lowest mean of 2.61 and this ranged from 2.52 to 2.70 . The result revealed marginal contribution of population growth rate to economic development in-spite of the growing population. However, the mean values of income inequality and education level was very high.

The skewness and kurtosis in the analysis provides explanation about the deviation from normal distribution and flatter shape or peakedness of the distribution. The result shows that corruption $(-0.6056)$ 
and education level (-0.332) are less than zero. The result simply means that the values of the two variables skewed to the right of the mean while the other variables values (Economic development, income inequality and population growth) have normal distribution. The kurtosis results reveals that economic development (12.264) has leptokurtic distribution which is sharper than a normal distribution with value concentrated around the mean and thicker tails with high means probability for extreme values kurtosis $>$ 3 , while income inequality rate (3.03) shows mesokurtic distribution, which is normal distribution with kurtosis approximately 3. Meanwhile, corruption and population growth and education level have platykurtic distribution, flatter than a normal distribution with a wider peak. The probability for extreme values is lesser than a normal distribution and the values are spread around the mean.

Table 3. Ordinary Least Square Regression Estimates

Dependent Variable: EDV

Method: Least Squares

Date: 04/10/19 Time: 11:52

Sample (adjusted): 20012017

Included observations: 17 after adjustments

\begin{tabular}{lcccc}
\hline \hline Variable & Coefficient & Std. Error & t-Statistic & Prob. \\
\hline \hline COR & -1.472422 & 0.557616 & -2.640564 & 0.0216 \\
INQ & -1.282806 & 0.425148 & -3.017318 & 0.0107 \\
POPG & 11.34571 & 15.87300 & 0.714780 & 0.4884 \\
EL & 1.326036 & 0.988808 & 1.341045 & 0.2047 \\
ECM(-1) & -0.666596 & 0.332507 & -2.004756 & 0.0481 \\
\hline \hline R-squared & 0.605189 & Mean dependent var & 3.976471 \\
Adjusted R-squared & 0.473585 & S.D. dependent var & 7.352766 \\
S.E. of regression & 5.334761 & Akaike info criterion & 6.426294 \\
Sum squared resid & 341.5161 & Schwarz criterion & 6.671357 \\
Log likelihood & -49.62350 & Hannan-Quinn criter. & 6.450654 \\
Durbin-Watson stat & 2.409986 & & &
\end{tabular}

\section{Discussion of Results and Test of Hypotheses}

The table reported the Ordinary Least Squared multiple regression results. According to the result, corruption has a negative coefficient and it is significant at the 2 percent level. The result suggests that there is an inverse relationship between corruption and economic development over a long period of time in Nigeria. It shows that the incessant increase in high profile corruption cases in Nigeria has damaging effects on the economic development in the period under study. The result further indicates that a percent incremental change in the scourge of corruption reduces the level of economic development in Nigeria by about 147 percent. This result is consistent with our apriori proposition. This finding is in consonance with the findings of Ambar (2015); Kwabena (2002); and Egunjobi (2013) but at variance with the findings of Ritva and Jakob (2005); and Chris (2014) who found a positive relationship between corruption and economic development. The finding is in line with the modernization theory of corruption that corruption generates political instability and has negative effect on economic development.

In the same vein, income inequality also showed a negative sign and it is significant at 2 percent. This result suggests an inverse relationship between the income inequality and economic development in Nigeria. It shows that a percent increase in income inequality reduces economic development by 128 percent. Thus, other things being equal, unnecessary wide gap between the rich and the poor may have contributed to low level of economic development in Nigeria. This finding is in consonance with the findings of Banerjee and Duflo (2000) but at variance with the findings of Forbes (2000) who found a positive relationship between income inequality and economic development. This is in agreement with sociological theory of corruption that the wide gap between the powerful (rich or people with political influence) and the powerless (poor or masses) brings about income inequality among people which in turn having negative effect on economic development. 
In contrast, population growth rate has positive coefficient and it is not statistically significant at 5 percent level. This result suggests a direct relationship between population growth and economic development in Nigeria. The result indicated that a percent increase in population growth rate increases economic development by 1134 percent. However, population growth is not statistically significant in explaining economic development. This is because the bulk of the population is skewed towards underage and in most cases unemployed and as such cannot contribute meaningfully to economic growth and consequently, development. Furthermore, education level is positively and directly related to economic development. The implication of this is that an improvement in the level of education of the people leads to economic development. In addition, result indicated that a percentage increase in the level of education increases economic development in Nigeria by 12 percent.

Finally, the coefficient of error correction mechanism $(-0.6665)$ is correctly signed, and significant at the 4 percent level of significance. The coefficient of the error correction term indicates an adjustment of about 66 percent from the actual changes in the previous years. Thus, the model will rightly act to correct any deviation from a long run equilibrium relation between economic development and the regressors (corruption, income inequality, and population growth rate and education level).

\section{Conclusions and recommendations}

\subsection{Conclusions}

The broad objective of this study was to investigate the effect of corruption and income inequality on economic development in Nigeria. The empirical analysis revealed that both corruption and income inequality has a significant relationship but negatively correlated with economic development. This result is an indication that increase in level of corruption in Nigeria will cause nothing but serious damage to economic development. Also, if income inequality (uneven distribution of the nation's wealth) increases or continues the way it is, Nigerian economic development will continue to suffer setbacks.

This result is an indication that corruption and income inequality are parts of the major factors that makes economic development in Nigeria to suffer setbacks. Therefore, it is crystal clear that corruption is one of the major obstacles to ensuring an improved economic development in Nigeria, there should be some strict and restrictive measures that must be taken in order to drastically control or reduce its negative impact on Nigerian economic development. However, the result gotten from this study should be treated with caution because the index of corruption used is based on perception which might not be true sometimes. Also, this perception does not indicate whether corruption is organized or not, centralized or decentralized, whether it involves high level or low level officials and the extent of pervasiveness in the Nigerian economy. Therefore, the result presented should be considered indicative (that is as a sign, suggestion or an indication) rather than explicitly or conclusive.

\subsection{Recommendations}

The findings in this work shows that both corruption and income inequality has a negative impact on economic development. This deadly virus tagged "corruption" has a way of affecting income inequality to the extent that the level of poverty increases, citizens not having access to sound health and education (that is reduction in human capital development), and reducing citizen's access to social welfare which is supposed to be provided by the government. All these factors have affected the economic development in Nigeria negatively. The government efforts in battling corruption over the years through the establishment of anti-graft agencies and anti-corruption crusades have failed to yield major dividend. This is an indication that, the entire actions channel towards tackling corruption and income inequality lacks forensic investigative backing. Since we are in democratic settings, no government has the absolute power to prosecute any corruption suspect except after being declared by the court of law that such person is guilty of the offence. Prevention, early detection and prosecution of any public officer found guilty of such offence would serve as a deterrent for others who may have corruption intent. In Nigeria today, some high profile corruption cases are lost by default because they lack forensic backing (enough evidences are not provided to justify their claims). In order to tackle this monster called corruption, which is rooted in Nigeria economy and reduce income inequality to barest minimum, the following are therefore recommended: 
i. Government should put in place controls that will block every loophole through the establishment of monitoring and evaluating agencies that will enforce control on over-budgetary spending and monitor the government expenditure by ensuring that it is judiciously expended on the purposes meant for, instead of diverting it for private benefit. That is, reforming public administration and finance management.

ii. Since corruption also increases income inequality and thereby have negative impact on economic development. It is an indication that monies appropriated on health and education, social welfare and so on are not effectively expended on them but rather diverted or embezzled. Therefore, government policies should be channeled towards improving citizens' standard of living through provision of basic social amenities and infrastructures. They should reduce their bureaucratic impediment to importation and legalities involve in establishing a business, this will reduce poverty rate and improve economic development.

iii. The fraud diamond theory suggests that the very first element that motivates people to be corrupt is pressure, which is mostly financial pressure. Corrupt activities that came as a result of financial pressure can be reduced by increasing workers' wages, increase incentive given for honest behavior, and establish strong and effective controls and penalties on guilty public servant to tackle corruption.

iv. Government can also block loopholes of corruption in Nigeria through the institution of sound corporate governance. Corporate governance focuses on the extent and nature of how people are accountable and transparent. If good corporate governance is promoted through integrity, transparency and accountability, the desired change can be brought into the country. To this end, the government must promote transparency and ensure all citizens have access to quality information.

v. Anti-Graft agencies against corruption and financial crimes in Nigeria such as ICPC, EFCC, Code of Conduct Bureau and so on should be strengthen through the establishment and use of forensic investigative skills that aids in generating enough evidences for quick and easy detection of corrupt activities and financial crimes in Nigeria, subsequently punishing the corrupt officials. Also, these agencies should be truly independent of Nigerian politics if they must perform effectively. Through this, the cycle of impunity will be broken and reduce corruption to barest minimum.

vi. International loopholes should be blocked in order to curb corrupt official access to the international financial system. This would prevent them in laundering and hiding the proceeds of the looted government funds.

vii. Government should use technological tools to develop institutional trust by automating tax collections, automatically sharing information across borders, and digitalization of public service activities. While doing this, every risk associated with technology use in fighting corruption should be dealt with thoroughly.

Conclusively, corruption is a major hindrance to the progress of any society or country. Restrictive measures must be put in place to reduce its' negative effect on economic development to barest minimum.

\section{References}

1. Adefulu, A. (2007). Neo patrimonialism the modern African state and corruption syndrome: A theoretical and empirical consideration in corruption and the challenges of human development. School of Management and Social Sciences. Babcock University Press.

2. Agubamah, E. (2009). Corruption in civilian and military regimes in Nigeria, a comparative analysis in anti-corruption reforms since 1999: Issues, challenges and the way forward. IFRA Special Research Issue, 3(1), 23-41.

3. Ambar, R. (2015). Corruption, inequality and economic growth. Journal of Economics and Finance, 5(15), 106-111.

4. Arias, O., Diaz, A., \& Fazio, M. (2013). Breaking the cycle of underinvestment in human capital in Latin America. World Bank flagship report: Poverty reduction and growth, virtuous and vicious circles, 9(1), 22-33.

5. Association of Certified Fraud Examiner. (2010). Report to the Nation on occupational fraud. Retrieved from https://acfe.com/documents/2010RttN.

6. Atkinson, A. B. (1970). On the measurement of inequality. Journal of Economic Theory, 2, 244-263. 
7. Bambra, C. (2004). The worlds of welfare: Illusory and gender blind? Journal of Social Policy and Society, 3(3), 201-211.

8. Banerjee, A. V., \&Duflo, E. (2000). Inequality and Growth what Can the Data Say. NBER Working Paper, (7793).

9. Barro, R. (1991). Economic growth in a cross section of countries. Quarterly Journal ofEconomics 106, 407-43.

10.Benabou, R. (1994). Human capital, inequality and growth: A local perspective. European Economic Review, 38 (3), 817-826.

11.Besley \& Cords. (2007). Delivering on the promise of pro-poor growth: Insights and lessons from country experience. World Bank.

12.Campbell, A. (1981). The scene of well-being in America.New York, USA: McGraw-Hill.

13.Caselli, F., Esquivel, G., \& Lefort, L. (1996). Reopening the convergence debate: A new look at cross-country growth empirics. Journal of Economic Growth 1(5), 363-389.

14.Chambers, D. (2005). Trading places: Does past growth impact inequality. Journal of Development Economics, 82(1), 257-266.

15.Chris, M. (2014). When corruption is good for the economy. Journal of Economic Perspective. Retrieved on the $4^{\text {th }}$ of August, 2017 from https://www.google.com.ng/amp/amp.timeinc.net/fortune /2014/08/07/corruption-economic-benefits/\%3fsource=dam.

16.Christian, J. C. (2013). Corruption and income inequality: A study of the impact from different legal systems. Jonkoping International Business School, Jonkoping University.

17.Dada, S. O. (2014). Forensic accounting technique: A means for successful eradication of corruption through fraud prevention, bribery prevention and embezzlement prevention in Nigeria. Kuwait Chapter of Arabian Journal of Business and Management Review, 4(1), 176-186.

18.Dincer, O. C., \& Gunalp, B. (2005). Corruption, income inequality and growth: Evidence from United States. Retrieved from http://www.rrojasdatabank.info/inequality/SSRN-id690381.

19.Dollar, David \& Kraay (2012). Growth is good for the poor. World Bank Policy Research Working Paper. Washington DC: World Bank

20.Eatzaz, A., Muhammad, A. U., \& Muhammad, I. A. (2012). Does corruption affect economic growth? Latin American Journal of Economics, 49(2), 25-29.

21.Egunjobi, T. A. (2013). An econometric analysis of the impact of corruption on economic growth in Nigeria. E3 Journal of Business Management and Economics, 4(3), 54-65.

22.Eckersley, R. (2004). The green state: Rethinking democracy and sovereignty. USA: Massachusetts Institute of Technology (MIT) Press.

23.Forbes, K. (2000). A reassessment of the relationship between inequality and growth. American Economic Review, 90(4), 869-886.

24.Gjinovci, A. (2016). The impact of nepotism and corruption on the economy and HR. Journal of Economic and Environmental Studies, 3(39), 421-434.

25.Gupta, S., Davoodi, H., Alonso-Terme, R. (1998). Does corruption affect income inequality and poverty? IMF Working Paper No. WP/98/76.

26.Gupta, Sanjeev, Hamid, D., \& Rose, A. (2002). Does corruption affect income inequality and poverty? Economic of Governance, 3, 23-45.

27.Gyimah-Brempong, K., Traynor, T. (1999). Political instability, investment, and economic growth in Sub-Saharan Africa. Journal of African Economies 8(1), 52-86.

28.Hall, R. E., \& Jones, C. I. (1999). Why do some countries produce so much more output per workers than others? The Quarterly Journal of Economics, 114, 83-116.

29. Hamra, W. (2000). Bribery in international business transaction and the OECD convention: Benefits and limitations. Business Economics, 35(4), 33-46.

30. Haq, M. (1995). Reflection of human development. Oxford New York: Oxford University Press

31.Hendriks, J., Keen, M., \&Muthoo, A. (1998). Corruption, extortion and evasion. University of Exeter Department of Economics Discussion Paper No. 98/09. 
32. Hoffmeyer-Zlotnik, J. H., \& Uwe, W. (2006). How to measure education in cross-national comparison: A matrix of education as a new instrument. European Conference on Quality in Survey Statistics 11(1), 223-240.

33.Iyanda, D. O. (2012). Corruption: Definitions, theories and concepts. Arabian Journal of Business and Management Review (OMAN Chapter), 2(4), 37-45.

34.Jain, A. (2001). Corruption: A review. Journal of Economic Survey, 15(1), 71-121.

35.Jenny, B., \&Erlinda, M. (2006). Anti-corruption and governance: The Philippine experience. AsiaPacific Economic Cooperation, 4, 1-28.

36.Jorge, A. C. (2011). Understanding income inequality: Concept, causes and measurement. International Journal of Economics and Management Sciences, 1(3), 17-28.

37.Josh, M. (2014). Corruption, income inequality and subsequent economic growth. Undergraduate Economic Review, 11(1), 1-20.

38.Kelly, M. K. (2015). Fraud and corruption practices in public sector: The Cameroonian experience. Research Journal of Finance and Accounting, 6(4), 203-209.

39.Kendall, J. (2000). Interpersonal trust and voluntary associations: Examining three approaches. The British Journal of Sociology, 53(3), 343-362.

40.Klitgaard, R. (1998). International cooperation against corruption. SPAN; Sept/Oct 1998 issue.

41.Knack, S., \& Keefer, P. (1997). Why doesn't poor country catch up? : A cross national test of an institutional explanation. Economic Inquiry, 35, 590-602.

42.Knoema. (2018). Corruption Perception Index. Retrieved from https://www.google.com/amp/ knoema.com/atlas/Nigeria/corruption-perception-index\%fmode=amp.

43. Kwabena, G. (2002). Corruption, economic growth, and income inequality in Africa. Economics of Governance, 3(1), 183-209.

44.Levine, R., \& Renelt, D. (1992). A Sensitivity Analysis of Cross-Country Growth Regressions. AmericanEconomic Review 82(4): 942-963.

45.Li, H., Xu, L. C., Zou, H. (2000). Corruption, income distribution and growth. Economics and Politics 12(2): 155-185.

46. Mankiw, G., Romer, D., \& Weil, D. N. (1992). A Contribution to the Empirics of Economic Growth.Quarterly Journal of Economics 107(2), 407-437.

47.Mauro, P. (1995). Corruption and growth. Quarterly Journal of Economics, 110, 681-812.

48. Mauro, P. (1997). The effect of corruption on growth, investment and government expenditure: A cross-country analysis. Corruption and the Global Economy Journal, 83, 34-45.

49.Organisation for Economic Cooperation and Development [OECD] (2004). Education at a glance, OECD indicators 2004. Paris: OECD Publications

50.Owolabi, S. A., Dada, S. O., \& Olaoye, S. A. (2013). Application of forensic accounting techniques in effective investigation and detection of embezzlement to combat corruption in Nigeria. Unique Journal of Business Management Research, 1(4), 65-70.

51.Ritva, R., \& Jakob, S. (2005). Fighting corruption to improve schooling: Evidence from a Newspaper campaign in Uganda. Journal of the European Economic Association, 3(3), 259-267.

52.Rothstein, B., \& Uslander, E. M. (2005). All for all: Equality, corruption and social trust. World Politics, 58(1), 41-72.

53.Sachs, J. D. (1989). Social conflict and populist policies in Latin America. National Bureau of Economic Research, 2897, 23-51.

54.Sachs, J., \&Warner, A. (1997). Fundamental Sources of Long-Run Growth. American Economic Review87(2): 184-188.

55.Seers, D. (1969). The meaning of development. International Development Review, 11(4), 3-4

56.Sen, A. (1999). Development of freedom. Oxford: Oxford University Press.

57.Shleifer, A., \&Vishny, R. W. (1993). Corruption. The Quarterly Journal of Economics, 108, 599-617.

58.Sinding, S. W. (2009). Population, poverty and economic development. Phil. Trans. R. Soc. B, 364(1), 3023-3030.

59.Soreide, T. (2002). Corruption in public procurement, causes, consequences and cures. Bergen: Chr. Michelsen Institute. 
60.Stephens, P., Leach, A., Jones, H., \& Taggart, L. (1998). Think sociology. Chettenham, United Kingdom: Nelson Thornes, Ltd.

61.Stiglitz, J. (1998). More instruments and broader goals: Moving toward the post-Washington consensus. World Institute of Developmental Economic Research Annual Lectures.

62.Taha-Barakat, A. (2016). Economic effect using nepotism and cronyism in the employment process in the public sector institutions. Research in Applied Economics, 8(1), 58-67.

63.Tanzi, V., \& Davoodi, H. (1997). Corruption, public investment and growth. IMF Working Paper No. WP/97/139.

64.Tato, M. (1998). Improving teacher education in Mexico: The challenges and tensions of constructivist reform. International Journal of Research and Studies, 9(1), 15-35.

65.Transparency International [TI]. (2009). The anti-Corruption Plain Language Guide by Transparency International, pp. 1-60.

66.Ugur, M., \& Dasgupta, N. (2011). Corruption and economic growth: A meta-analysis of the evidence on low-income countries and beyond. Munich Personal RePec Archive, pp. 1-43.

67. Ugwu, E. I. (2012). Economic growth and poverty in Nigeria: Is growth pro-poor? Evidence from existing data sets. M. Sc. Thesis, University of Nigeria.

68.Viorica, D., Jemna, D., \& Pintilescu, C. Determinants of corruption in Romania and its impact on economic growth. Analele Stiintificeale Universitatii Alexandru Loan Cuza din lasi-Stinte Economice, 58(1), 225-233.

69.Wahiba, N. F. (2014). The relationship between economic growth and income inequality. International Journal of Economics and Financial Issues, 4(1), 135-143.

70.Wei, S. (2000). How taxing is corruption on international investors? Review of Economics and Statistics, 82(1), 1-11.

71.Wu, X., Golan, A., \& Perloff, J. M. (2002). Effects of government policies on income distribution and welfare. Mimeo.

\section{APPENDIX: Data Used for the Study}

Selected Data Used for the study

\begin{tabular}{cccccc}
\hline YEAR & EDV\% & COR\% & INQ\% & PGR\% & EL\% \\
\hline 1999 & -2 & 16.00 & 55.00 & 2.54 & 41.50 \\
2000 & 2.7 & 12.00 & 56.00 & 2.52 & 41.50 \\
2001 & 1.8 & 10.00 & 53.20 & 2.52 & 41.50 \\
2002 & 1.2 & 16.00 & 45.08 & 2.52 & 41.50 \\
2003 & 7.6 & 14.00 & 40.10 & 2.52 & 44.30 \\
2004 & 30.4 & 16.00 & 40.06 & 2.52 & 46.20 \\
2005 & 0.8 & 19.00 & 40.72 & 2.58 & 46.50 \\
2006 & 5.4 & 22.00 & 41.74 & 2.58 & 47.50 \\
2007 & 4.1 & 22.00 & 41.89 & 2.58 & 47.90 \\
2008 & 3.5 & 27.00 & 42.90 & 2.58 & 48.50 \\
2009 & 4.1 & 25.00 & 43.00 & 2.58 & 49.00 \\
2010 & 5 & 24.00 & 43.90 & 2.68 & 48.40 \\
2011 & 2.1 & 24.00 & 44.50 & 2.68 & 49.40 \\
2012 & 1.5 & 27.00 & 45.10 & 2.68 & 51.20 \\
2013 & 2.6 & 25.00 & 45.70 & 2.68 & 51.90 \\
2014 & 3.5 & 27.00 & 46.30 & 2.68 & 52.40 \\
2015 & 0 & 26.00 & 46.90 & 2.70 & 52.70 \\
2016 & -4.2 & 28.00 & 47.50 & 2.65 & 53.00 \\
2017 & -1.8 & 27.00 & 48.10 & 2.63 & 53.20 \\
\hline
\end{tabular}

Source:
i. $\quad$ CBN Statistical Bulletin (2018);
ii. United Nation Statistical Data (2018);
iii. World Bank Data (2018);
iv. Transparency International Index (2018). 